\section{Cureus}

Received 04/26/2019

Review began 05/03/2019

Review ended 05/19/2019

Published 05/23/2019

\section{(c) Copyright 2019}

Odhaib et al. This is an open access article distributed under the terms of the Creative Commons Attribution License CC-BY 3.0., which permits unrestricted use, distribution, and reproduction in any medium, provided the original author and source are credited.

\title{
How Biotin Induces Misleading Results in Thyroid Bioassays: Case Series
}

\author{
Samih A. Odhaib ${ }^{1}$, Abbas A. Mansour ${ }^{2}$, Nazar S. Haddad ${ }^{3}$ \\ 1. Diabetes and Adult Endocrinology, Faiha Specialized Diabetes, Endocrine and Metabolism Center, \\ College of Medicine, University of Basrah, Basrah, IRQ 2. Diabetes and Endocrinology, College of \\ Medicine, University of Basrah, Basrah, IRQ 3. Iraqi Board of Medical Specializations In Clinical \\ Chemistry (fibms. Chem. Path.), American Association for Clinical Chemistry (faacc), College of \\ Medicine, University of Basrah, Basrah, IRQ
}

$\square$ Corresponding author: Samih A. Odhaib, samihabedodhaib@gmail.com Disclosures can be found in Additional Information at the end of the article

\section{Abstract}

Biotin is widely available over the counter in different doses and is used medically in the management of hair and nail problems. Recent literature suggested the use of high doses of biotin for the treatment of progressive multiple sclerosis. We present four cases that show a misleading increase in thyroid function tests toward a false diagnosis of Grave's disease after the administration of 20-30 mg biotin for different periods. All the four cases are free of the signs and symptoms of hyperthyroidism, and all of their results returned to baseline values within 24-48 hours after biotin withdrawal. The assemblage of these cases, thyroid assay results, and biotin doses had occurred by chance, with no selection bias, and they represented all cases of biotin interference with thyroid assays in our center during this year. The first case is a 23-year-old female who was diagnosed with Grave's disease during a routine checkup after she ingested a prescribed $20 \mathrm{mg}$ biotin per day for three months for excessive hair fall. The second case is a 19-year-old female with hair and nail problems associated with iron deficiency anemia. She administered a self-prescribed biotin dose of $20 \mathrm{mg}$ a day for a month. She asked an endocrinologist's opinion about a recent increase in her thyroid function tests, with no signs of hyperthyroidism. The third case is a 45-year-old man with near-total thyroidectomy for retrosternal multinodular goiter with compressive symptoms. His usual levothyroxine dose had been decreased from 100 to 50 microgram per day, after which he felt unwell and gained four kilograms, with signs and symptoms of hypothyroidism. His investigations were consistent with hyperthyroidism while his signs were of hypothyroidism, which was illogical. He was administered $30 \mathrm{mg}$ medically prescribed biotin for nail changes due to recently diagnosed psoriasis. The fourth case is that of one of the authors who volunteered to take $30 \mathrm{mg}$ of biotin daily for one week. His initial investigations were in the normal range but changed within this period to be Grave's disease-like, with no signs or symptoms. In conclusion, the ingestion of 20 mg or more of biotin may lead to a clinically relevant thyroid assay interference. The clinicians must take this point in consideration before assessing the results of any thyroid function tests.

Categories: Endocrinology/Diabetes/Metabolism

Keywords: biotin, thyroid bioassay, immunoassay, grave's disease, pseudohyperthyroidism

\section{Introduction}

Biotin is a negatively charged, water-soluble B complex vitamin (B7, B8, or H) [1] and an essential cofactor in the activation of many biotin-dependent carboxylases [2]. The primary site of biotin absorption is the intestinal brush border, with a 110 minutes plasma half-life [1]. Biotin is covalently bound to proteins, polypeptides, and low molecular weight antigens, 
forming the biotinyl-lysine complex after the digestive breakdown of biotin-containing protein $[1,3]$.

Generic formulations of biotin, up to $10 \mathrm{mg}$ (100-200 times higher than the standard dietary reference intake (DRI) estimates of 17-70 $\mu \mathrm{g}$ ), are widely available over the counter [2]. Recently, the high-dose biotin (HDB) (100 mg to $300 \mathrm{mg} /$ day, which is 10,000 times the DRI) was vital in the management of progressive multiple sclerosis [4]. Biotin affects the acetyl CoA carboxylase activation mechanism as a cofactor in myelin production through the promotion of oligodendrocytes-dependent remyelination by enhanced fatty acid synthesis and the prevention of demyelinated axons degradation by increased energy production [5].

There are several, rare, inherited metabolic diseases that can benefit from the HDB (e.g., biotinidase deficiency: 5-10 mg/day; holocarboxylase synthetase deficiency: 30-40 mg/day; biotin-thiamine-responsive basal ganglia disease: 100-300 mg/day) [6-7]. Doses up to $30 \mathrm{mg} /$ day are now widely used for improving hair, nail, or skin condition [6] and for supportive treatment in mitochondrial energy metabolism disorders, lipid disorders, and diabetic peripheral neuropathy $[3,7]$.

There are many new generation thyroid bioassays that depend on the streptavidin-biotin complex as the immobilizing method or affinity tag to improve the sensitivity amplification especially in detecting low analyte levels [8].

We present four cases that illustrate the temporarily marked effect of biotin administration interference with the thyroid bioassays.

\section{Case Presentation}

\section{Case 1: mistaken as Grave's disease}

DS is a 23-year-old married female who came for the evaluation of accidentally discovered high thyroid function readings during the treatment course for excessive hair fall. She was referred from a fellow dermatologist, to have a second opinion about the possibility of Grave's disease.

On initial interview, DS appeared calm and not in any distress. Her past and recent medical history were noncontributory, apart from the excessive hair fall in the past three months, for which she sought the dermatologist's advice for treatment by topical creams and lotions, alongside with biotin as a hair tonic in a dose of $10 \mathrm{mg}$ twice daily. General and systemic examinations were noncontributory.

Her investigations gave a picture of Grave's disease, yet she was free of symptoms or signs. So, we advised her to repeat the assays (Table 1). Her thyroid ultrasound examination was normal. We reviewed the results and advised DS to quit biotin for the following 24 hours and to repeat the tests afterward to ensure the diagnosis of thyroid bioassay interference by biotin ingestion (Table 1). It took 48 hours for the biotin interference to disappear. 


\section{Cureus}

\begin{tabular}{|c|c|c|c|c|c|}
\hline \multirow[b]{2}{*}{ Investigations } & \multicolumn{2}{|l|}{ On biotin } & \multicolumn{2}{|l|}{ Off biotin } & \multirow[b]{2}{*}{$\begin{array}{l}\text { Normal } \\
\text { values }\end{array}$} \\
\hline & $\begin{array}{l}\text { October } 10^{\text {th }} \text {, } \\
2018^{\pi}\end{array}$ & $\begin{array}{l}\text { October } 12^{\text {th }} \\
2018^{\text {ITा }}\end{array}$ & $\begin{array}{l}24 \text { hours after } \\
\text { discontinuation } \pi \text { Tा }\end{array}$ & $\begin{array}{l}48 \text { hours after } \\
\text { discontinuation }\end{array}$ & \\
\hline $\mathrm{TSH} \mu \mathrm{IU} / \mathrm{ml}$ & 0.05 & 0.06 & 0.52 & 1.44 & $0.27-4.2$ \\
\hline FT4 ng/dl & 2.93 & 3.11 & 1.99 & 1.08 & 0.93-1.7 \\
\hline FT3 pg/ml & 6.09 & 6.93 & 4.51 & 2.31 & $1.21-4.18$ \\
\hline 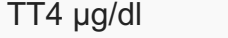 & 15.12 & 14.87 & 6.44 & & 5.1-14.1 \\
\hline Anti-TPO IU/ml & 6.33 & & & & $0-34$ \\
\hline TRAb mlU/ml & 4.74 & 5.0 & 1.96 & & $<2$ \\
\hline Tg ng/ml & 19.76 & & & & $1.40-78$ \\
\hline Anti-Tg IU/ml & 33.62 & & & & $0-115$ \\
\hline \multicolumn{6}{|c|}{$\begin{array}{l}\text { TS Snibe Maglumi } 800 \text { immunoassay. }{ }^{\text {TTा }} \text { Roche Cobas e411 immunoassay. TSH: Thyroid-Stimulating Hormone, FT4: Free } \\
\text { Thyroxine, FT3: Free Triiodothyronine, TT4: Total Thyroxine, Anti-TPO: Antithyroid Peroxidase, TRAb: Thyrotropin } \\
\text { Receptor Antibody. Tg: Thyroglobulin. Anti-Tg: Anti-Thyroglobulin. }\end{array}$} \\
\hline
\end{tabular}

\section{TABLE 1: Thyroid function test of a 23-year-old female with a wrong diagnosis of Grave's disease after $20 \mathrm{mg} /$ day biotin therapy for excessive hair fall.}

\section{Case 2: pseudohyperthyroidism}

ZR is a 19-year-old married female who had a history of iron deficiency anemia (IDA) and polycystic ovary syndrome (PCOS), with bothersome androgenic alopecia, hirsutism, and nail changes. A fellow gynecologist referred ZR for assessing recently discovered elevated thyroid function tests.

On initial interview (November 24, 2018), her assessment was noncontributory, apart from her complaint of hair, nail, and infertility problems. In the previous three months, she took regular $300 \mathrm{mg}$ ferrous sulfate daily for the treatment of her IDA, with a treatment regimen for her PCOS in the form of spironolactone tablet $100 \mathrm{mg}$ twice daily, finasteride tablet $5 \mathrm{mg}$ once daily, and metformin tablets $1700 \mathrm{mg}$ daily. She confessed to ingest a $20 \mathrm{mg}$ self-prescribed biotin daily for the last month as a hair tonic, as instructed by many hair care websites. Her initial investigations (three months ago) included an optimal basal thyroid function test and ultrasound, with biochemical and clinical evidence of PCOS and IDA.

After repeating the thyroid function tests in our laboratory, we believed that the main culprit was the $20 \mathrm{mg}$ biotin that caused such interference with the thyroid bioassay (pseudohyperthyroidism). We advised ZR to discontinue biotin and to repeat the test after 24 hours. Some of her tests returned to baseline after 24 hours while the free thyroxine (FT4) needed 72 hours to return to its baseline level, as shown in Table 2. 


\section{Cureus}

\begin{tabular}{|c|c|c|c|c|c|c|c|}
\hline \multirow{2}{*}{ Investigations } & \multirow{2}{*}{$\begin{array}{l}\text { Initial investigations Aug } \\
30,2018\end{array}$} & \multicolumn{2}{|c|}{ On biotin } & \multicolumn{3}{|l|}{ Off biotin } & \multirow{2}{*}{$\begin{array}{l}\text { Normal } \\
\text { values }\end{array}$} \\
\hline & & $\begin{array}{l}\text { Nov 22, } \\
2018\end{array}$ & $\begin{array}{l}\text { Nov 24, } \\
2018\end{array}$ & $\begin{array}{l}24 \text { hours } \\
\text { after }\end{array}$ & $\begin{array}{l}48 \text { hours } \\
\text { after }\end{array}$ & $\begin{array}{l}72 \text { hours } \\
\text { after }\end{array}$ & \\
\hline TSH $\mu \mathrm{IU} / \mathrm{ml}$ & 0.86 & 0.04 & 0.05 & 1.04 & 1.11 & & $0.27-4.2$ \\
\hline FT4 ng/dl & 1.63 & 3.23 & 3.48 & 2.55 & 2.30 & 1.04 & $0.93-1.7$ \\
\hline FT3 pg/ml & & & 4.01 & 2.24 & & & $1.21-4.18$ \\
\hline $\mathrm{TT} 4 \mu \mathrm{g} / \mathrm{dl}$ & 14.00 & 22.12 & 20.17 & 10.30 & & & $5.1-14.1$ \\
\hline TT3 ng/ml & 0.9 & 4.21 & 4.56 & 1.56 & & & $0.8-2$ \\
\hline Anti-TPO IU/ml & & & 3.22 & & & & $0-34$ \\
\hline TRAb mlU/ml & & & 0.68 & & & & $<2$ \\
\hline
\end{tabular}

TABLE 2: A 19-year-old female with pseudohyperthyroidism due to self-prescribed 20 $\mathrm{mg} /$ day biotin for hair and nail changes in iron deficiency anemia and polycystic ovary syndrome

\section{Case 3: false reduction of the thyroxin dose}

HA is a 45-year-old man who underwent a near-total thyroidectomy on April 22, 2018, for retrosternal multinodular goiter with compressive symptoms. He was administered $100 \mu \mathrm{g}$ levothyroxine daily, with a good clinical outcome. He had regular checkups, as adviced by his surgeon. HA was well until September 16, 2018, when his surgeon decreased the thyroxine dose to $50 \mu \mathrm{g} /$ day, after high readings of thyroid function tests during his routine visit. HA did not feel well, and he was exhausted all the time, with four kilograms' additional weight gain, constipation, and disturbed sleep with low mood.

The surgeon referred HA for an endocrinologist's opinion on January 2, 2019. His previous investigations revealed hyperthyroidism that ran in discrepancy with the patient's symptoms of hypothyroidism, which was evident clinically during the initial assessment. We performed another set of thyroid tests that gave the diagnosis of TRAb-positive Grave's disease, which was illogical for us and HA.

After again going through the drug history, we discovered that HA was additionally administered a $30 \mathrm{mg}$ biotin tab daily as prescribed treatment for his nail changes due to recently diagnosed psoriasis. HA never mentioned biotin in his drug history because he believed that biotin is a vitamin, not a drug. We advised him for biotin withdrawal and repeated investigation after 24 hours.

After biotin discontinuation, the TSH returned to normal in 24 hours and was on the low side after 48 hours while the FT4 and FT3 needed 48 hours to return to baseline. The TRAb turned 


\section{Cureus}

negative after 72 hours. HA received his usual $100 \mu \mathrm{g} /$ day thyroxine again. We scheduled the next visit to be on February 20, 2019, at which there were no signs of the original complaint with the pre-biotin thyroid hormone level (Table 3).

\begin{tabular}{|c|c|c|c|c|c|c|c|c|c|c|}
\hline \multirow[b]{2}{*}{ Investigations } & \multicolumn{4}{|c|}{ 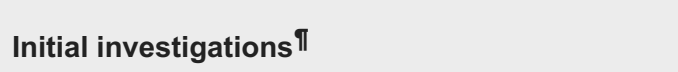 } & \multirow{2}{*}{$\begin{array}{l}\text { On } \\
\text { biotin Tा } \\
\text { January } \\
\text { 2, } 2019\end{array}$} & \multicolumn{3}{|c|}{ Off biotin ПTा } & \multirow{2}{*}{$\begin{array}{l}\text { Feb } \\
20, \\
2019\end{array}$} & \multirow[b]{2}{*}{$\begin{array}{l}\text { Normal } \\
\text { values }\end{array}$} \\
\hline & $\begin{array}{l}\text { Before } \\
\text { operation } \\
\text { April 22, } \\
2018\end{array}$ & $\begin{array}{l}\text { To start } \\
\text { thyroxin } 100 \\
\mu g / d \text { May 20, } \\
2018\end{array}$ & $\begin{array}{l}\text { July } \\
1^{\text {st }}, \\
2018\end{array}$ & $\begin{array}{l}\text { September, } \\
16,2018 \\
\text { thyroxin } 50 \\
\mu \mathrm{g} / \mathrm{d}\end{array}$ & & $\begin{array}{l}24 \\
\text { hours } \\
\text { after }\end{array}$ & $\begin{array}{l}48 \\
\text { hours } \\
\text { after }\end{array}$ & $\begin{array}{l}72 \text { hours after } \\
\text { and restart } \\
\text { thyroxin } 100 \\
\mu \mathrm{g} / \mathrm{d}\end{array}$ & & \\
\hline $\mathrm{TSH} \mu \mathrm{lU} / \mathrm{ml}$ & 1.24 & 13.13 & 5.01 & 0.05 & $<0.05$ & 2.11 & 6.34 & 6.92 & 3.59 & $\begin{array}{l}0.27- \\
4.2\end{array}$ \\
\hline FT4 ng/dl & 0.96 & 0.52 & 1.04 & 2.67 & 5.03 & 3.32 & 1.42 & 0.90 & 1.45 & $\begin{array}{l}0.93- \\
1.7\end{array}$ \\
\hline FT3 pg/ml & 1.52 & 0.91 & 3.11 & 2.09 & 12.11 & 5.05 & 2.15 & 0.91 & 3.06 & $\begin{array}{l}1.21- \\
4.18\end{array}$ \\
\hline TT4 $\mu \mathrm{g} / \mathrm{dl}$ & 5.55 & & 9.07 & 15.4 & 15.31 & 10.09 & & & & $\begin{array}{l}5.1- \\
14.1\end{array}$ \\
\hline TT3ng/ml & 0.98 & & & & & & & & & $0.8-2$ \\
\hline $\begin{array}{l}\text { Anti-TPO } \\
\mathrm{IU} / \mathrm{ml}\end{array}$ & 6.17 & & & & 8.77 & & & & & $0-34$ \\
\hline TRAb mlU/ml & 0.857 & & & & 9.3 & 4.233 & 3.32 & 1.68 & 0.92 & $<2$ \\
\hline $\mathrm{Tg} \mathrm{ng} / \mathrm{ml}$ & 52.09 & & & & 71.30 & 22.28 & & & & $1.40-78$ \\
\hline Anti-Tg IU/ml & 92.96 & & & & 54.81 & & & & & $0-115$ \\
\hline
\end{tabular}

TABLE 3: Wrong diagnosis of Grave's disease in a 45-year-old male with near-total thyroidectomy on $100 \mu \mathrm{g} /$ day thyroxine due to $30 \mathrm{mg} /$ day biotin therapy for nail changes of psoriasis.

\section{Case 4}

One of the authors volunteered to take $30 \mathrm{mg}$ of biotin daily for one week to simulate - to an extent - the possible biotin dose interference in the three aforementioned cases. The results of his initial investigation done in his annual checkup on February 24, 2019, are shown in Table 4. There was a biochemical picture of hyperthyroidism, with no signs or symptoms to be experienced by him. All the investigations returned to average baseline values after 24 hours of discontinuation of biotin. 


\section{Cureus}

\begin{tabular}{|c|c|c|c|c|}
\hline \multirow{2}{*}{ Investigations $\mathbf{s}^{\mathbb{\pi}}$} & \multirow{2}{*}{ Initial investigations Feb 24, 2019} & On biotin & Off biotin & \multirow{2}{*}{ Normal values } \\
\hline & & Feb 26, 2019 & 24 hours after & \\
\hline $\mathrm{TSH} \mu \mathrm{IU} / \mathrm{ml}$ & 1.45 & 0.8 & 1.33 & $0.27-4.2$ \\
\hline FT4 ng/dl & 1.36 & 1.94 & 1.24 & $0.93-1.7$ \\
\hline TT4 $\mu \mathrm{g} / \mathrm{dl}$ & 10.06 & 7.32 & 6.94 & 5.1-14.1 \\
\hline TT3 ng/ml & 1.4 & 2.77 & 1.91 & $0.8-2$ \\
\hline Anti-TPO IU/ml & 15.47 & 54.87 & 12.5 & $0-34$ \\
\hline TRAb mlU/ml & 0.770 & 6.97 & 1.2 & $<2$ \\
\hline $\mathrm{Tg} \mathrm{ng} / \mathrm{ml}$ & 7.12 & 6.32 & & $1.40-78$ \\
\hline Anti-Tg IU/ml & $<10.00$ & 25.18 & 7.45 & $0-115$ \\
\hline \multicolumn{5}{|c|}{$\begin{array}{l}\text { I Roche Cobas e411 immunoassay. TSH: Thyroid-Stimulating Hormone, FT4: Free Thyroxine, TT4: Total Thyroxine, } \\
\text { TT3: Total triiodothyronine, Anti-TPO: Antithyroid Peroxidase, TRAb: Thyrotropin Receptor Antibody, Tg: Thyroglobulin, } \\
\text { Anti-Tg: Anti-Thyroglobulin }\end{array}$} \\
\hline
\end{tabular}

\section{TABLE 4: Thyroid function tests of a 41-year-old adult endocrinologist who volunteered to be administered $30 \mathrm{mg} /$ day biotin for a week}

\section{Discussion}

The interference of biotin with the thyroid bioassays is evident in all four cases, and it disappears after biotin withdrawal. Being chemiluminescent biotinylation-based assays with nearly the same normal reference values, the Roche Cobas e411 and Snibe Maglumi 800 bioassays gave results pointing toward the diagnosis of pseudohyperthyroidism and even Grave's disease, led, in part, to wrong medication changes, as in Case 3, and warranted further unnecessary investigations, as in Cases 1 and 2 . This interference works in vitro only, with no real clinical effect, i.e., it is biochemical.

The streptavidin-biotin complex represents one of the most robust non-covalent interactions in nature. This complex is not disturbed by multiple washing steps, and biotinylation typically does not alter the biological activity or immunologic specificity when bound to a test molecule $[6,9]$.

This methodology is currently widely used in several Food and Drug Administration (FDA)approved immunoassay systems using fully automated platforms, including Access, DxI, and DxC (Beckman Coulter, California, US); the Elecsys, Cobas, and Modular platforms (Roche Diagnostics, Basel, Switzerland); the Isys platform (Immuno Diagnostic System, East Boldon, United Kingdom); the Ortho Vitros platform (Ortho Clinical Diagnostics, New Jersey, US); the Dimension Vista, Exl, Immulite platforms (Siemens Healthineers, Erlangen, Germany), Abbott Architect i2000 ${ }^{\circledR}$ (Abbott Diagnostics, Illinois, United States), and Diasorin Liaison XL ${ }^{\circledR}$ (DiaSorin, Saluggia, Italy) due to its small molecular weight of 244.3 Dalton [6,10-11].

Low biotin doses in vitamin supplements are not thought to interfere with bioassays, though 
some manufacturers mention the interference potential for anyone taking biotin $>5 \mathrm{mg} / \mathrm{day}$ [11]. This supraphysiological HDB in blood has produced an emerging problem with insidiously misleading immunoassays results (for the biotin-streptavidin binding that accounts for about half of all current immunoassays), fully mimicking and indistinguishable from the typical biochemical picture of Grave's disease and sometimes persisting for several days after biotin withdrawal $[3,8,12]$. This interference occurs through complex mechanisms that involve either interfering with the analytical system themselves or by influencing their endogenous constituents [9]. The minimal dose required for interference and the degree, duration, and magnitude of this erroneous interference to occur is not known and might be analyte-specific and challenging to assess $[9,13]$.

The artifact result is falsely increased hormone concentrations using competitive assays (e.g., T3, T4, steroid hormones, 25-OH vitamin D) and falsely decreased hormone concentrations using sandwich assays (glycoprotein-regulating hormones) [6,14]. These opposite effects may lead to pseudohyperthyroidism, with apparently elevated free thyroxine and free triiodothyronine and lowered thyroid-stimulating hormone concentration [3,6,12,15-16]. Sharma et al. illustrated some cases with a false elevation of the anti-TSH receptor antibody (TRAb) titers, suggesting Grave's disease, leading to additional inappropriate therapy [14], the effect that was affirmative in two of our patients (Cases 1 and 3).

In the free thyroxine competitive immunoassays, we incubate the serum sample with a ruthenium-linked anti-thyroxine antibody complex, and then the added biotinylated thyroxine will bind unoccupied excess sites on this complex $[13,15]$. The biotinylated T4-antibody complex then attaches to the streptavidin-coated tube, or microparticles on the solid phase, and generates chemiluminescence signals by the alkaline phosphatase conjugate and chemiluminescent substrate [16-18].

This chemiluminescence is inversely proportional to the free analytes in the sample [12-13,15]. A high biotin concentration in the sample saturates the streptavidin-binding sites and prevents the streptavidin binding to the biotinylated-analyte, resulting in a little or no labeled T4antibody complex binding to the solid phase and, hence, a falsely elevated free thyroxine level $[13,15]$.

In sandwich immunoassays, we incubate the serum sample with a mixture of biotinylated monoclonal TSH antibody and ruthenium-labeled monoclonal TSH antibody to allow immune complexes formed between the two antibodies and TSH. The solid phase captures these complexes via the streptavidin-coated magnetic microparticles. The chemiluminescence produced by ruthenium upon voltage application will be directly proportional to serum TSH $[16,18]$.

A significant biotin excess in the serum saturates the streptavidin binding sites, thereby resulting in reduced binding of the immune complexes to the solid phase and, hence, a falsely low TSH level $[6,8]$.

The Roche's (TRAb) bioassay is also a biotin-streptavidin competitive binding assay [3], explaining the elevated levels seen in our case series. The Access TSH bioassay does not use biotin-streptavidin interaction as compared to the Access fT4 and fT3 bioassays, which are competitive binding immune-enzymatic assays, using a monoclonal anti-T4 antibody coupled to biotin and a biotinylated T3 analog, respectively, in their assay design $[10,18]$. The interference disappears for an immunoassay using no biotin such as the Advia Centaur ${ }^{\circledR}$ (Siemens Healthineers), showing the patient's actual thyroid functions [16].

Older studies had revealed a decrease in the thyroglobulin level in patients taking different 
doses of biotin because the thyroglobulin bioassay is a sandwich biotinylation-based assay $[10,15]$. The thyroglobulin level had decreased in the fourth case, but we could not find any explanation for its increase in the third case after biotin discontinuation.

After biotin discontinuation, interference may disappear within eight to 48 hours, but TRAb can take up to seven days to normalize [12,18]. It took 48-72 hours to turn to normal in our patients (Cases 1 and 3).

There is a concern that the results of many other hormonal and non-hormonal immunoassays (troponin, natriuretic peptides, ferritin, tumor markers, therapeutic drug assays, infectious markers, ferritin, human chorionic gonadotropin, steroid and polypeptide hormones, parathyroid hormone, estradiol, testosterone, dehydroepiandrosterone sulfate, etc.) may be misleading because of biotin interference $[6,13,19]$.

\section{Conclusions}

In this case series, the ingestion of the widely used biotin of $20 \mathrm{mg}$ or more for different reasons and different periods led to a potent and clinically relevant thyroid bioassay interference in all the four cases presented here. The clinicians should consider these findings in patients taking biotin supplements of any dose before ordering a thyroid function assay and when interpreting the results. The biotin should be discontinued for at least 48-72 hours before thyroid assaying by any commonly used biotin-streptavidin immunoassay.

\section{Additional Information \\ Disclosures}

Human subjects: Consent was obtained by all participants in this study. Conflicts of interest: In compliance with the ICMJE uniform disclosure form, all authors declare the following:

Payment/services info: All authors have declared that no financial support was received from any organization for the submitted work. Financial relationships: All authors have declared that they have no financial relationships at present or within the previous three years with any organizations that might have an interest in the submitted work. Other relationships: All authors have declared that there are no other relationships or activities that could appear to have influenced the submitted work.

\section{Acknowledgements}

The authors thank the laboratory staff of the Faiha Specialized Diabetes Endocrine and Metabolism Center for their help and assistance.

\section{References}

1. McMahon RJ: Biotin in metabolism and molecular biology. Annu Rev Nutr. 2002, 22:221-239. 10.1146/annurev.nutr.22.121101.112819

2. Zempleni J, Mock DM: Biotin biochemistry and human requirements. J Nutr Biochem. 1999, 10:128-138.

3. Elston MS, Sehgal S, Du Toit S, Yarndley T, Conaglen JV: Factitious Graves' disease due to biotin immunoassay interference - a case and review of the literature. J Clin Endocrinol Metab. 2016, 101:3251-3255. 10.1210/jc.2016-1971

4. Tourbah A, Lebrun-Frenay C, Edan G, et al.: MD1003 (high-dose biotin) for the treatment of progressive multiple sclerosis: a randomised, double-blind, placebo-controlled study. Mult Scler J. 2016, 22:1719-1731. 10.1177/1352458516667568

5. Sedel F, Papeix C, Bellanger A, et al.: High doses of biotin in chronic progressive multiple sclerosis: a pilot study. Mult Scler Relat Disord. 2015, 4:159-169. 10.1016/j.msard.2015.01.005

6. Piketty M, Prie D, Sedel F, Bernard D, Hercend C, Chanson P, Souberbielle J-C: High-dose 
biotin therapy leading to false biochemical endocrine profiles: validation of a simple method to overcome biotin interference. Clin Chem Lab Med. 2017, 55:817-825. 10.1515/cclm-20161183

7. Henry JG, Sobki S, Arafat N: Interference by biotin therapy on measurement of TSH and FT4 by enzyme immunoassay on Boehringer Mannheim ES700 analyser. Ann Clin Biochem. 1996, 33:162-163. 10.1177/000456329603300214

8. Li D, Radulescu A, Shrestha RT, et al.: Association of biotin ingestion with performance of hormone and nonhormone assays in healthy adults. JAMA. 2017, 318:1150-1160.

10.1001/jama.2017.13705

9. Sturgeon CM, Viljoen A: Analytical error and interference in immunoassay: minimizing risk . Ann Clin Biochem. 2011, 48:418-432.

10. Revet I, Boesten LSM, Linthorst J, Yildiz E, Janssen JW, Rijke YB, Albersen A: Misleading FT4 measurement: assay-dependent antibody interference. Biochem Med (Zagreb). 2016, 26:436443. 10.11613/BM.2016.046

11. Minkovsky A, Lee MN, Dowlatshahi M, et al.: High-dose biotin treatment for secondary progressive multiple sclerosis may interfere with thyroid assays. AACE Clin Case Rep. 2016, 2:e370-e373. 10.4158/EP161261.CR

12. Kummer S, Hermsen D, Distelmaier F: Biotin treatment mimicking Graves' disease. NEJM. 2016, 375:704-706. 10.1056/NEJMc1602096

13. Al-Salameh A, Becquemont L, Brailly-Tabard S, Aubourg P, Chanson P: A somewhat bizarre case of Grave's disease due to vitamin treatment. J Endocr Soc. 2017, 1:431-435. 10.1210/js.2017-00054

14. Sharma A, Baumann NA, Shah P: Biotin-induced biochemical Graves disease: a teachable moment. JAMA Intern Med. 2017, 177:571-572.

15. Barbesino G: Misdiagnosis of Graves' disease with apparent severe hyperthyroidism in a patient taking biotin megadoses. Thyroid. 2016, 26:860-863.

16. Simó-Guerrero O, Giménez-Pérez G, Recasens-Gracia A, Villà-Blascoa C, Castells-Fustéb I: False overt hyperthyroidism by interference in immunoassay. Endocrinol Nutr. 2016, 63:431432.

17. Jun-Guan TAN, Tar-Choon AW: Biotin effects on thyroid function test . Annals Thyroid Res. 2018, 4:149-150.

18. Kwok JS, Chan IH, Chan MH: Biotin interference on TSH and free thyroid hormone measurement. Pathology. 2012, 44:278-280. 10.1097/PAT.0b013e3283514002

19. Koehler VF, Mann U, Nassour A, Mann WA: Fake news? Biotin interference in thyroid immunoassays. Clin Chim Acta. 2018, 484:320-322. 10.1016/j.cca.2018.05.053 